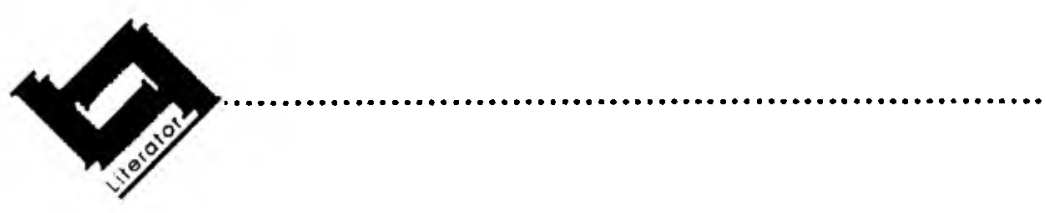

\title{
Women and transformation: A recurrent theme in Head and Ngugi ${ }^{1}$
}

\author{
Nettie Cloete \\ Department of English Studies \\ University of the North \\ SOVENGA
}

\begin{abstract}
Women and transformation: A recurrent theme in Head and Ngugi

This article evaluates, within the context of the increasingly important position assigned to African literature in general (and the novel in particular), the dominant roles played by Bessie Head and Ngugi through a focus on the significant contributions of these two writers concerning the theme of women and transformation. Although both authors put a high premium on womanism, showing themselves as champions of especially sexual and racial freedom for all women, their novels indicate different trends in their portrayal of this theme. Head, for instance, becomes increasingly autobiographical in her articulation of her female protagonists' struggle for freedom from oppression, while Ngugi tends to become increasingly politically biased in expressing his Marxist social, political and economic doctrines. This article furthermore examines the ways in which Ngugi and Head highlight different aspects of the discourse of female liberation, while also studying the dialogue of transformation and a sense of belonging. Finally, it remarks on Head's and Ngugi's aesthetic approaches to the discourse of women and transformation.
\end{abstract}

\section{Contextualization}

While African writing has established itself as one of the most important fields of contemporary literature, provoking increasing interest in the domain of comparative literature, female/feminist postcolonial literature, including the works

1 Financial assistance of the HSRC for my primary research is hereby acknowledged. 
of a large number of African women, it has also been recognized as a significant facet of the literary output of the twentieth century. At a crucial time in the histories of South Africa and Africa, and with the emergence of an ever more significant role for women on the continent, it might be useful to look at the place and role of women in African societies as depicted by two major African writers, Bessie Head (South Africa and Botswana [as an exile]) and Ngugi wa Thiong'o (Kenya).

In this article Head and Ngugi are used as exemplars of two generally opposing ideas on women and transformation, because Ngugi's position as a leading novelist would provide a useful foil for the more focused view on difference and otherness evinced by Head. Ngugi is considered by distinguished critics ${ }^{2}$ as the doyen of African (male) novelists. His representations of women, however, in many ways are traditional and patriarchally stereotypical, although his empathy with the victims of oppression does at times extend to women as a marginalized group. Bessie Head, on the other hand, regarded by some as the foremost woman novelist of the continent ${ }^{3}$, assumes an overtly feminist stance in her work although her stance is defined more by a general awareness of abuses of power, not just the abuse of women. Her writing is a clear attempt to write women into history, from whence they have been resolutely and traditionally excluded. She is, therefore, a woman writer who has

... resorted to an effective, quietly devastating subversion of the traditional stereotypical roles ascribed to women by asserting their independence and rewriting literature and, by implication, history - and thus finally and irrevocably (re)-inscribing themselves into history (Wenzel, 1995:Abstract).

\section{Relevance of the present article}

This comparative approach reveals remarkable similarities and differences in Head's and Ngugi's portrayal of women and change, culminating in male and female views on this important issue within the African continent. These arise both from the gender perspective and from the different background political

2 Gerard (1981:312) regards Ngugi as "one of the finest novelists in black Africa, as perhaps the best writer to have come not only from his country Kenya, but from the whole of what used to be British East Africa".

3 Maxwell-Mahon (1992:39) mentions this fact in his article "Out of Africa: A Tribute to Bessie Head":

Doris Lessing, Nadine Gordimer, Mary Morrison Webster, Sheila Fugard, Sheila Roberts - we all know who they are ... but Bessie Head? Who is she? Well, on the grounds of literary merit rather than the promotion of this or that racial or political ideology, she is one of the finest novelists to come out of Africa. 
situations which have had a profound influence on the worldview of these two authors.

A study of transformation within the context of post-colonialism is currently relevant, especially for South Africans, who are part of one of the most sweeping and exciting transformations in world history. More changes, both in number and kind, have taken place in the postcolonial period than in any previous era.

The novels of Ngugi and Head underscore Achebe's proverbial words forming the title of his 1975 critical essay, namely that it is still not Uhuru in the fullest sense of the word, but Moming Yet on Creation Day. Thematically, both Head's and Ngugi's major novels thus represent their authors' rendering of central issues of current literary and critical concern. In other words, although their novels deal with matters and ideas that still preoccupy their contemporaries, they contain much that is unconventional and characteristic of each of these writers. Some of these aspects will therefore be analysed in the rest of this article.

\section{Women and transformation in the fiction of Head and Ngugi}

\subsection{Aułobiographical versus political writing}

The contrasting views held by Head and Ngugi concerning the nature and aim of fiction have shaped their portrayal of women in a changing society. While Head used fiction as a means of solving her own inner conflict in coming to terms with life as a lonely, stigmatized, exiled Other, Ngugi has increasingly relied on fiction to further his political interests. Although Bessie Head is not insensitive to the impact of colonialism on traditional African society, she does not, like Ngugi, extensively explore pre-colonial cultures to show how colonialism destroyed them. Head's work, for instance the stories in The Collector of Treasures (1983), reveals the realities of life in traditional society while her novels often depict the processes by which old realities have been changed because of contact with foreign influences. Ngugi, by contrast, often criticizes colonialism and the destructive effects of foreign influences on traditional society.

In a letter to Charles Sarvan in $A$ Woman Alone (Head, 1990:13) on 26 June 1980 Bessie Head stated that all three of her novels "are continuous autobiographical records". When Rain Clouds Gather (1968) testifies to Head's concern with the personal experiences of lonely exiles, experiences that she identified with. In Maru (1971) Head's preoccupation with displaced, stigmatized and persecuted female characters is also indicative of the sensitive woman writer struggling to come to terms with, and to realize her artistic talents in what she perceives as a hostile environment. However, the foundational autobiographical premises of $A$ Question of Power (1973) have elicited ambivalent reactions from critics, often 
questioning the validity of Head's conception of the novel as thinly veiled autobiography. Moreover, the personal trend is already discernible in Head's earlier novella, The Cardinals (1993), where Mouse clearly resembles the young Bessie Head.

Head's fiction reveals that she does not view the novel as a realist genre but rather employs it as a subjective vehicle which plays a constructive and cathartic role in solving her own personal anxieties. Lewis Nkosi (1981:102) is understandably critical of the autobiographical nature of Head's novels. He feels that the "passion to make the feature of personal experience a governing emotion" may result in becoming "a compulsive disposition" in the works of any writer, especially in those of a so-called "protest" writer. In consequence, he justifies the inclusion of personal details in a novel only when it serves as an incentive to artistic creation:

Nevertheless, where a writer is absolutely in control over the materials of his life the pressure acts as a necessary key which unlocks the imagination and provides us with the necessary means for reconciling the author's private world of subjectivity with the objective world of universal significance (Nkosi, 1981:102).

Nkosi (1981:102) views Bessie Head as "a writer who throws in every flotsam and jetsam" of her private life into a novel "in an untested supposition that we, as readers, will find significance in it". Although essentially an autobiographical and highly committed author, Bessie Head is not a political writer. Nkosi, for example, states: "Bessie Head is not a political novelist in any sense we can recognise; indeed, there is ample evidence that she is generally hostile to politics". He feels that Head's self-avowed political resentment has a negative influence on her character portrayal. I, however, agree with Virginia Ola (1994: 4), who maintains that although Head writes against the background of her own struggle against discrimination, the "totality" of her characters as human beings "transcends politics".

Paradoxically, Head herself ascribes one of the most appealing characteristics of her work, namely her connectedness to Africa, to her admiration for Robert Sobukwe. In $A$ Woman Alone she states in a letter to Charles Sarvan (25 April 1980):

I dearly loved Robert Sobukwe and the politics he expounded ... Sobukwe's view was Pan African and generally included all things African, with an edge of harshness in it that forced one to make an identification with being African and a sense of belonging to Africa. This helped me to adjust and get a sense of balance. Mostly, all black people bom in South Africa, live with a very broken sense of history. Apart from this slight acquaintance with the 
world of politics, I have carefully avoided power and politics both in a personal capacity and in my work (Head, 1990:13 - my emphasis: NC).

Ngugi's basic artistic premise, which informs his portrayal of women in a changing world, by contrast, may be interrogated on the opposite grounds: he progressively views his novels as a means by which to express his Marxist political, social and economic ideology. Nemoianu's (1995:3) criticism of the manner in which colonialism was forced on the indigenous populations in the world at large, and in Africa in particular, serves to justify Ngugi's bitterness at the painful effects of colonization discemible in a postcolonial Kenyan society:

... the aggressive initiative and military-political dynamism of Western civilization led it to assert its domination over the rest of the world. No dispute here: there is much truth in this explanation, Western civilization having shown from its very beginnings a very energetic willingness to expand and to use force in its self-affumation (Nemoianu, 1995:3).

Ngugi's rejection of the new African ehtist rulers who practise and even revel in their abuse of power and their exploitation of the proletariat - in particular of females - as especially Petals of Blood (1977) and Devil on the Cross (1982) so forcefully demonstrate, is an essential part of his increasing urge to use literature as a means of political and social protest in post-independence Kenya. According to Kathy Kessler (1994:79) Ngugi "positions women in the narrative and in the historical context in ways that foster the renovation of identity and tradition and redefine their roles in the development of a revolutionary consciousness". In Matigari (1987), however, Ngugi's avowed aim of creating "a work that seeks to stir people to revolt ... may be argued as creating not literature but propaganda" (Pelton, 1993:19). Pelton expresses the opinion, shared by a large number of critics and readers alike, that "the quality of Ngugi's fiction may have suffered ... having become a political figure ... Ngugi has become less effective ... as a creative artist" (Pelton, 1993:19). I, nevertheless, believe that Ngugi's concern, fundamentally, is always with concrete human relationships, exposing how they have been destroyed by the injustices of colonialism and postcolonialism.

It is thus evident that in her depiction of women in a changing world Bessie Head's aversion to politics may be regarded as a limitation to her work, while Ngugi's insistence on using the novel for propagating certain political ideas reveals an inclination towards pamphleteering.

\subsection{The discourse of female liberation}

Both Head and Ngugi deny the traditional female discourse of the African woman as being dominated, exploited, abused and merely used as a beast of burden. In other words, Head and Ngugi may both be regarded as feminist writers, according to Cherryl Walker's (1991:xxiii) definition that "a feminist is someone 
who perceives that women in a given society are oppressed as women, and beheves that this should be changed". A chronological study of female characters in the novels of these two authors indicates a new conception of empowered women because the female protagonists usually grow in strength and influence as each novel develops and also in the writers' output as a whole.

Brown (1980:180) distinguishes an interesting feature in Head's empowerment of women:

The importance of private growth as a prerequisite for social change is more explicit in the works of Bessie Head than in ... [the works of many female African writers], but she is representative rather than unique in this regard. In retrospect, all the major writers are preoccupied with the woman's personal strength - or lack of it - when they analyse sexual role and sexual inequality.

Bessie Head's female protagonists are often stronger and more resilient than their male counterparts. Her novels are characterized by "the predominance of female over male protagonists, the tendency to endow the heroines with sympathyevoking qualities and the unusually articulate nature of these heroines" (Achufusi, 1991:356). This portrayal of female protagonists induces Achufusi to note in Head a pronounced determination "to destroy the male stereotypes of women" (Achufusi, 1991:356). However, Head's female protagonists also reflect the author's own uncertainty about basic roots: they are portrayed as the characters of "a writer whose status in this world is further compromised by her sex, by her social and cultural past, by her political insights and particularly by her status of many years, as a person without a nationality" (Ibrahim, 1988:5). Ibrahim therefore regards Bessie Head as a "third world woman writer for whom the sinister structures of anglophile colonial oppression still exist under South African apartheid, and for whom the battle against actual as well as abstract colonialism is not yet over" (Ibrahim, 1988:5).

Paulina Sebeso, the female protagonist of Head's When Rain Clouds Gather ${ }^{4}$, dominates the novel. She settles in Golima Mmidi with her two children after her Rhodesian husband's suicide. She is portrayed as a woman who scorns tradition and custom by refusing to pretend to be inferior to men: "A few men had said she was too bossy. Thien they all said it, overlooking the fact that they were wilting, effeminate shadows of men who really feared women" (WRCG:93). She is introduced into the novel as one of the "strong, dominating personalities who play

4 Henceforth the following abbreviations are used for Head's novels:

When Rain Clouds Garher - WRCG

Maru - M

A Question of Power - AQOP 
a decisive role when things are changing. Somehow they always manage to speak with the voice of authority, and their innate strength of character drives them to take the lead in almost any situation" (WRCG:75). Paulina's submission to Makhaya is also not the blind adherence of the ordinary tribeswoman to male authority. It rather indicates her willingness to marry and look up to a man she can really respect, a man who has developed in the course of the novel to be worthy of her love.

The three important female characters in Maru, Margaret Cadmore Senior, Margaret and Dikeledi, are examples of females who support change. In Head's oeuvre Margaret Cadmore Senior is one of the clearest examples of a woman who possesses remarkably stronger and more refined qualities than her male counterpart, her husband George. She is "highstrung, nervous, energetic" (M:12), able to take charge of any situation, has abundant common sense and is always on the progressive side. Her husband, however, is described as "naturally dull and stupid only people never noticed [it] because he was a priest and mercifully remained silent for hours on end" (M:12). The depiction of Margaret reveals Head's belief in the uniqueness of every human being. She emphasizes Margaret's superiority over oppression because of her talented nature nurtured and developed by an unbiased education. Although quietly resolute, her endearing qualities win the love and respect of Maru and initiate change in the village. Dikeledi also has a profound influence on effecting change. She is intelligent, has "style and class", and impresses "people as someone worth noticing and listening to" (M:9). She is "a drastic revolutionary" (M:25) who immediately recognizes Margaret's true worth. Her willingness to scorn tradition and befriend Margaret plays a crucial role in changing traditional perceptions about oppression. The male characters, by contrast, have more pronounced weaknesses. Moleka lacks the courage to marry Margaret, Maru is unwilling to accept the paramountcy, while Pete and Seth openly voice scom of women and the Masarwa.

In A Question of Power, by contrast, Elizabeth's battle against hostile forces is limited to regaining her own sanity and a feeling of unity with her community. Her contribution to transformation is therefore more limited than that of her predecessors and especially of Ngugi's major female characters. The novel relates how Elizabeth regains her sanity after two nervous breakdowns from which she emerges as a stronger person who finds roots in her community and the ability to relate to other people:

She had fallen from the very beginning into the warm embrace of the brotherhood of man, because when a people wanted everyone to be ordinary it was just another way of saying man loved man. As she fell asleep, she placed one soft hand over her land. It was a gesture of belonging (AQOP:206). 
She moreover finds spiritual consolation when she realizes that "There is only one God and his name is Man. And Elizabeth is his prophet" (AQOP:206). Because the male characters in the novel are mainly seen through Elizabeth's distorted and turbulent mind, they are ambivalent. As a result, Sello and Dan are "not the real human characters of conventional literature, rather they are aspects of Elizabeth's mind, concretized in her fertile imagination" (Pearse, 1983:88). Both men, however, have a negative effect on Elizabeth. The benign side of Sello in which the redemptive figure of Buddha plays a vital role, soon becomes malignant when he taunts her by conjuring up images of his wife Medusa, thereby scorning Elizabeth's lack of sexuality as well as her fear of homosexuality. Dan's destructive power lies in his ability to deceive Elizabeth.

Ngugi's female protagonists in turn become increasingly resourceful as the novels progress. Muthoni and Nyambura in The River Between ${ }^{5}$ represent the rudiments of Ngugi's perception of the ideal woman - a woman who believes in change, is prepared to suffer for the attainment of her beliefs, and has the courage to speak out fearlessly to defend her convictions. Muthoni dies in her attempt to unite Christianity with traditional religion when she defies her father's censure of circumcision:

'I too have embraced the white man's faith. However, I know it is beautiful, oh so beautiful to be initiated into womanhood. You learn the ways of the tribe. Yes, the white man's God does not quite satisfy me. I want, I need something more' (RB:29-30).

Ngugi's sensitivity and psychological insight are evident in his subtle portrayal of the difference between the two sisters. Where the younger Muthoni opposes her father with daring and disregard for the consequences of her rebellion, the older sister displays more tact and understanding of her parent's traditional views. Ngugi intensifies the dilemma of his female characters in this difficult time of acculturation by revealing that the mother, Miriamu, who represents the traditional female role, nevertheless also has reservations about her husband's surrender to Christianity, when he "gets swept wholesale into the Christian religion" (Gachukia, 1971:30).

Despite moments of lonely agony Mwihaki, the young protagonist of Weep Not, Child (1964), constantly portrays more self-confidence and realism than Njoroge,

5 Henceforth the following abbreviations are used for Ngugi's novels:

The River between - RB

Weep not Child - WNC

A Grain of Wheat - GOW

Petals of Blood - POB

Devil on the Cross - DOC 
the male protagonist. She assumes greater significance as a character because she serves as a yardstick against whom Njoroge is constantly measured, a comparison that reveals him as selfish and negative: "He looked at her tears and wanted to wipe them. She sat there, a lone tree defying the darkness, trying to instil new life into him. But he did not want to live. Not this kind of life. He felt betrayed" (WNC:133). Njoroge's two mothers may also be viewed as more progressive than Miriamu in that Nyokabi takes a lead in getting Njoroge educated, while they serve as pillars of strength in the virtually destroyed household after the death of the father and his elder sons and the spiritual death of Njoroge

The same pattern is discernible in the depiction of male/female relationships in Ngugi's next novel, $A$ Grain of Wheat (1967). Where Gikonyo has an inferiority complex, Mumbi is more self-assured and capable of action. Gikonyo's mother, Wangari, refuses to accept defeat when her husband, Waruhiu, beats and rejects her, accusing her of sexual coldness. She displays undaunted courage when she settles in Thabai with her baby son for whom she also later secures some knowledge of carpentry. Wambui introduces the active role of women in the Mau Mau struggle, while Karanja's mother, Wairimu, mirrors Nyokabi's defiance of the traditional submissive female role because she questions the actions of men: where Nyokabi anticipates the consequences of a failed strike, Wairimu displays traditional wisdom in warning Karanja against joining the ranks of the white oppressors by becoming a despised home guard: "Don't go against the people. A man who ignores the voice of his people comes to no good end" (GOW:196).

Wanja and Wariinga, the female protagonists of Ngugi's next two novels, Petals of Blood (1977) and Devil on the Cross (1982), may be regarded as even stronger figures than their predecessors. The convincing creation of these two protagonists as regenerated urban women attests to Ngugi's understanding of the predicament of females in a post-independence state. In no way does Ngugi shy away from tackling recent challenges facing women whose innocence has been abused and who in different ways overcome the crisis of an illegitimate pregnancy as well as sexual exploitation and harassment in the more modern business world. Both Wanja and Wariinga succeed in taking a strong stand in combating general social ills by acting for the good of their people: they courageously endeavour to eradicate what they perceive as the root of their own personal and societal ills. Wanja resolves to break with her past and assert herself:

Wanja had made a pact with herself. She would have a completely new beginning in Ilmorog. Since she had left Ilmorog she had had two humiliating and shameful experiences. She would now break with that past and make something of herself in Ilmorog. As an evidence of her cleansed spirit, she resolved that she would not again obey the power of her body over men; that any involvement was out until she had defeated the past through a new flowering of self (POB:106-107). 
Munira comments on the change in Wanja: "It was a new youthful, life-full, luscious growth after the rains" (POB:155).

Wariinga in particular proves that it is "in the towns that women have staked their claim for equality most strongly" (Walker, 1991:3). The novel shows that Wariinga has benefited from the new freedom and educational opportunities for women, but has suffered from emotional stresses which women fighting male exploitation are subjected to. Despite her transformation from a scared, suicidal young girl into a mature, self-reliant woman who radiates poise and refinement "Wariinga, the black beauty! Wariinga of the mind and hands and body and heart, walking in rhythmic harmony on life's journey! Wariinga, the worker!" (DOC:218) - Wariinga is compelled to destroy her only chance of finding true happiness when she shoots The Rich Old Man. She regards this as a sacrificial act: "I'm not going to save you. But I shall save many other people" (DOC:253).

Unfortunately, Ngugi's most recent novel, Matigari (1987), does not continue its author's increasing skill at portraying females representative of their times. Guthera lacks the authenticity of the earlier female protagonists, while her efforts at assisting Matigari's quest for liberation merely repeat earlier actions of more convincing female protagonists. As a fairly flat or static character, she lacks the vivacity and life so characteristic of the portrayal of Ngugi's earlier vivid young female protagonists, whose more convincing creation may herald the height of Ngugi's achievement in his depiction of courageous and resilient young women.

To summarize, Head's more markedly autobiographical stance limits the opportunities for effecting the radical and more encompassing kind of change that Ngugi's strong and increasingly militant women achieve so convincingly. Despite employing converse discourses, both writers nevertheless succeed in creating a range of credible female characters.

\subsection{The dialogue of transformation and a sense of belonging}

This leads us to the third aspect of interest in the depiction of women and transformation: the dialogue of transformation and a sense of belonging. Naipaul (1967:248) underlines the importance of a sense of belonging as an incentive to human action: "A man, I suppose, fights [for transformation as well] only when he hopes, when he has a vision of order, when he feels strongly there is some connection between the earth on which he walks and himself'.

Naipaul's statement pinpoints the difference which underlies the striving for transformation in the novels of Head and Ngugi. Because Ngugi was a rooted Kenyan citizen when he started publishing his novels, his passionate love for his country must be seen as the driving force behind one of his most powerful themes, transformation into a new Kenya, a Kenya where the inhabitants can 
develop the country, to live in peace and security by reaping the benefits of struggle and change.

The opposite applies to Bessie Head. She struggled for almost all her mature life to achieve "a sense of belonging", to transform the hearts of the people to accept racial and sexual equality. Medusa, in A Question of Power, for instance, articulates Head's agonized struggle to achieve a precarious sense of belonging in what Head has experienced as a cold, inhuman and unwelcoming new country: "Africa is troubled waters, you know. I'm a powerful swimmer in troubled waters. You'll only drown here. You're not linked up to the people" (AQOP:44). Because alienation signifies having no roots in the community, Sello feels "I am just anyone" (AQOP:11), a statement which encapsulates Head's mental agony and which she herself regards "as one of the most perfect, and a very African one" (in Barnett, 1985:123). Conversely, Barnett explicitly connects rootedness in Africa, as opposed to rootedness in a country, as a common feature in the novels of Head and Ngugi: "Belonging also means having one's roots firmly planted in the land. In her grasp of the significance of land in Africa, both as a symbol and a fact, Bessie Head is perhaps nearest to the Kenyan writer Ngugi wa Thiong'o".

It is thus clear that in sharing a feeling of Africanness, both Head and Ngugi may be regarded as active advocates of dismantling the myth of the "culture of silence' of the dispossessed" (Freire, 1970:10).

\subsection{Head's and Ngugi's aesthetic approach to the discourse of women and transformation}

The lasting value of the works of Head and Ngugi may also be attributed to their dismantling another notion (still being propagated when they wrote their novels) that the main functions of African literature are its capacity for moralistic, educational, sociological, historical, and political instruction. This belief has been expounded by both African and non-African writers and critics, such as Achebe and Palmer6. Achebe (1965:204), for instance, states:

Here, then, is an adequate revolution for me to espouse - to help my society regain its belief in itself and put away the complexes of the years of denigration and self-denigration. And it is essentially a question of education in the best sense of that word. Here, I think, my aims and the

6 It would, however, be just as damaging to overlook the significant number of critics, such as Soyinka and Mphahlele, who have fairly constantly and incisively applied true literary criteria in their pronouncements about the nature of African literature, as well as in their practical application of these norms in their evaluation of individual literary products. 
deepest aspirations of my society meet ... I would be quite satisfied if my novels (especially the ones set in the past) did no more than teach my readers that their past - with all its imperfections - was not one long night of savagery from which the first Europeans acting on God's behalf delivered them. Perhaps what I write is applied art as distinct from pure. But who cares? Art is important but so is education of the kind I have in mind.

Bessie Head has never indicated any desire to use literature to promote any doctrines because of her uncommitted stance towards politics as well as to South Africa and later to Botswana. The essentially autobiographical nature of her novels reveals her struggle to find her own identity and a sense of belonging through the cathartic effects of writing. Despite Ngugi's open pronouncements about his use of writing as a means of effecting change, none of his novels may be regarded as a sentimental endeavour to capture the perceived romantic nature of traditional African life. Although his first novel, The River between (1965), reflects the beauty and orderliness of traditional Gikuyu customary life, it introduces the realities of initial changes in this African society. Ngugi's ensuing novels all deal with aspects of change and colonization. An important characteristic of Ngug's novels, therefore, is the increasingly important role which the theme of transformation assumes in his literary career, in his novels as well as in his dramas, political treatises, and short stories.

Moreover, an examination of stylistic aspects of Head's and Ngugi's novels establishes that these novels can in no way be regarded as so intensely preoccupied "with themes and the neglect of form, and thus the failure to be concemed about the estabhshment of a tradition" (Wake, 1969:50). The mere concentration on theme at the expense of form poses a threat to any essentially committed, and especially to a politically committed artist because it weakens the impact and durability of such a writer's work ${ }^{7}$. The novels of Head and Ngugi intrinsically satisfy because they display a high degree of "internal coherence"

7 In his very early appraisal of critical criteria for the evaluation of African literature, Clive Wake (1969:49-50) already cautioned against the abuse of commitment

Commitment can be creative, in the literary sense, but it can also destroy a creation. In other words, is the African literature of the present and immediate past simply going to be a land of literature that, in a few years will be of interest only to sociologists and historians, or the academic historians? Even at the moment it is receiving an amount of attention from sociologists that seems ominous to the literary critic. Essentially, the danger is that there is a serious temptation for writers to be inspired too much by the more ephemeral features of the present, making creative writing an agent of political revolution, and failing to send its roots deeper into the more sunstantial [sic] soil so as to bring about its own, although parallel revolution. 
(Ndebele, 1994:22) rather than "a high level of explicit political pre-occupation which may not necessarily be critically aware of the demands of the artistic medium chosen" (22-23), to apply Ndebele's critical yardstick to Head and Ngugi.

Head and Ngugi both employ a mytho-historical approach to literature: a method "whereby socio-historical phenomena are explored and explained within a framework of myth-and-history" (Achufusi, 1991:343). This approach is not new in world literature, but relatively novel to African literature. In Head's novels this approach culminates in $A$ Question of Power where myth and fact are at times so closely intertwined that they virtually become inseparable:

Bessie Head is the first female African writer (at least the first major one with internationally circulated works) to portray African social realities consistently on such a large canvass in which myth and history interpenetrate each other. Consequently, though she may be described as working within established traditions when viewed in the total context of world literatures (and even African literature), she is certainly an innovator when considered within the smaller sector African women's writing (Achufusi, 1991:344).

In Ngugi's novels, especially in his later novels such as Petals of Blood and Devil on the Cross, Marxist social and political doctrine is expressed in terms of class struggles within a framework established by history and myth. This aspect is noticeable even in Ngugi's first novel, The River Between, in that Chege, solely on the grounds of legends and ancestral belief, regards his son Waiyaki as the predestined natural leader whose duty is to effect change. He views his son as the descendant in the line of legendary leaders. In Ngugi's fourth novel, Devil on the Cross, however, a clear distinction exists between the elitist ruling classes and the ordinary citizens, a distinction based on money and power. In this regard his work is comparable to that of Wole Soyinka and Yambo Ouologuem, writers who also expose, and by implication criticize, the postcolonial tendency of empowering a small but privileged group of society, completely disregarding the traditionally respected group of leaders.

\section{Conclusion}

This article attempted to indicate, inter alia, that the novels of Bessie Head and Ngugi are products of artistic strength exceeding the constraints the merely documentary or didactic impulse would lead to. They are likely to become lasting literary landmarks, because they propound the deepest desires and longings of their creators. In the words of Rubadiri (1964:16): they do not like "this literature of protest, assertion and declamation ... [produce] writing which lacks balanced sensitivity and has tended to cloud the understanding of values which, above all, 
society requires of an artist". Iyasere (1972:5) validly mentions that "if the function of literature is to [merely] create an atmosphere for social change ... what distinguishes political pamphleteering from works of art"? In addition, he poses the probing question about the future of such literary creations after the desired change has been effected ${ }^{8}$. The increasing interest in Head's and Ngugi's novels thus proves that they are significant literary works, in their portrayal of women and transformation as well.

To conclude: the novels of Bessie Head and Ngugi are fully contemporary. They reveal the authors' sincere striving, through the freedom of postcolonial fiction, to change Africa into a freer and more unbiased continent. These two writers have courageously laboured to move away from the constraints of "the old language of the West" (Wicomb, 1992:15), in this instance specifically the unjustness of racial and sexual domination and exploitation. In the words of Mphahlele (1974: 78), writers such as Bessie Head and Ngugi "came in during the most exciting epoch in African life - at a time when things are taking shape". In this regard Ngugi's own words in Homecoming (1972:47) may be adapted. Head and Ngugi himself succeed in fulfilling their roles as the "sensitive needles" of society: they have definitely reflected "with varying degrees of accuracy and success, the conflicts and tensions" in their transforming societies.

\section{Bibliography}

Achebe, C. 1965. The Novelist as Teacher. In: Press, J. (ed) Commonwealth Literature. London : Heinemann.

Achebe, C. 1975. Morning Yet on Creation Day. London : Heinemann

Achufusi, Ifeyinwa G. 1991. Female African Writers and Social Criticism. A Study of the Works of Bessie Head and Grace Ogot. Madison : University of Wisconsin. (Ph.D thesis.)

Barnett, Ursula A 1985. A Vision of Order: A Study of Black South African Literature in English (1914-1980). Cape Town : Maskew Miller.

Brown, L. W. 1980. Women Writers in Black Africa. Westport Conn : Greenwood.

Freire, P. 1970 Pedagogy of the Oppressed. New York : Seabury Press.

Gachukia, Eddah. 1971. The Role of Women in Ngugi's Novels. Busara, 3(4):30-33.

Gérard, A S 1981 African Language Literatures: An Introduction to the Literary History of Sub-Saharan Africa. Essex : Longman.

Head, Bessie A. 1968 (1987). When Rain Clouds Gather. New York : Simon \& Shuster

Head, Bessie A. 1971 (1980). Maru London : Gollancz.

Head, Bessie A. 1973 (1987). A Question of Power. London : Davis-Poynter.

Head, Bessie A. 1983. The Collector of Treasures and Other Botswana Village Tales. London : Heinemann

8 lyasere (1972:5) here cites as examples of protest literature that have faded into "obscurity and oblivion because of their failure to respond to the essential qualities of significant form" Dostoevsky's Poor Folk, the "literature" of the French Resistance and Benjamin Disraeli's The Young Duke. 
Head, Bessie A. 1990. A Woman Alone: Autobiographical Writings. Mackenzie, C. (ed). Oxford : Heinemann.

Head, Bessie A. 1993. The Cardinals with Meditations and Short Stories. Daymond, M. (ed) Cape Town : Clyson Printer.

Ibrahim, Huma. 1988. Bessie Head: A Third World Woman Writer in Exile. Indiana : Indiana U.P.

Iyasere, S.O. 1972. The Rhetoric of African Fiction. Birmingham : State University of New York. (Ph D thesis.)

Kessler, Kathy. 1994. Rewriting History in Fiction: Elements of Postmodernism in Ngugi wa Thiong'o's later Novels. Ariel, XXV:75-90.

Maxwell-Mahon, W.D. 1992. Out of Africa: A Tribute to Bessie Head Lantern, 41(4):39-43

Mphahlele E. 1974. The African Image. London : Faber.

Naipaul, V.S. 1967. The Mimic Men. London : André Deutsch.

Ndebele, NS 1994. South African Literature and Culture: Rediscovery of the Ordinary Johannesburg : Creda Press.

Nemoianu, V. 1995. Globalism, Multiculturalism, and Comparative Literature. Unpublished Conference Paper, SAVAL Workshop, PUCHE.

Ngugi wa Thiong'o. 1964 (1987). Weep Not Child. London : Heinemann

Ngugi wa Thiong'o. 1965 (1987). The River Between London : Heinemann

Ngugi wa Thiong'o. 1967 (1980). A Grain of Wheat London : Heinemann.

Ngugi wa Thiong'o. 1972. Homecoming: Essays on African and Caribbean Literature, Culture and Politics London : Heinemann.

Ngugi wa Thiong'o. 1977 (1987). Petals of Blood. London : Heinemann.

Ngugi wa Thiong'o. 1982 (1987). Devil on the Cross. London : Heinemann

Ngugi wa Thiong'o. 1987. Matigari. London : Heinemann.

Nkosi, L. 1981. Tasks and Masks: Themes and Styles of African Literature. Essex : Longman

Ola, Virginia U. 1994. The Life and Works of Bessie Head Lewiston : Edwin Mellen Press.

Pearse, A. 1983. Apartheid and Madness: Bessie Head's A Question of Power. Kunapipi, $5(2): 81-93$

Pelton, T. 1993 Ngugi wa Thiong'o and the Politics of Language. The Humanist, V:15-20.

Rubadiri, D. 1964. Why African Literature? Transition, 4(15):12.

Wake C. 1969. The Political and Cultural Revolution. In: Pieterse, C. \& Munro, D. (eds) Protest and Conflict in African Literature. New York : Africana Publishing House.

Walker, Cherryl. 1991. Women and Resistance in South Africa. Johannesburg : David Philip.

Wenzel, Marita J. 1995. Literary Convention as a Feminist Strategy: The Nature and Function of the Picaresque in Selected Novels by Women Authors from Latin America and South Africa, 1970-1990. Potchefstroom : PUCHE. (Ph.D. thesis.)

Wicomb, Zoe. 1992. Nation, Race and Ethnicity: Beyond the Legacy of Victims Current Writing, 4:15-20. 
